\title{
Alleviation of oxidative stress induced by spider mite invasion through application of elicitors in bean plants
}

\author{
S. Farouk ${ }^{1 *} \&$ M. A. Osman ${ }^{2}$ \\ 1 Department of Agricultural Botany, Faculty of Agriculture, Mansoura University, Mansoura, Egypt. \\ 2 Department of Agricultural Zoology, Faculty of Agriculture, Mansoura University, Mansoura, Egypt.
}

\begin{abstract}
Spider mite invasion induces oxidative stress on bean plants and increased soluble sugars, phenole, proline and peroxidase activity, but decreased catalase activity and ascorbic acid and carotenoid concentration. Application of elicitors significantly enhanced spider mite tolerance by decreasing hydrogen peroxide, malondialdehyde, electrolyte leakage, and increasing peroxidase activity and antioxidant compounds reported previously, leading to increasing ion percentage in plant shoot. This finding suggests that elicitors might be activating antioxygenic enzymes and elevating antioxidants there by controlling free radical generation, hence preventing membrane peroxidation and denaturation of biomolecules resulting into improving plant growth.
\end{abstract}

Keywords: Tetranychus urticae, Phaseolus vulgaris, salicylate, methyl jasmonate, antioxidants.

\section{Introduction}

With a projected increase in world population to 10 billion over the next four decades, an immediate priority for agriculture is to achieve maximum production of food and other products in a manner that is environmentally sustainable and cost-effective. Losses due to insect herbivores, estimated at 10-20\% for major crops, are a significant factor in limiting food production. The Two-spotted spider mite (TSSM), Tetranychus urticae Koch (Acari: Tetranychidae) is considered a major pest decreasing plant growth and yield on different agricultural crops including bean plants (Farouk \& Osman 2009).

In response to pest invasion, plants mount a broad range of defence responses, including the generation of reactive oxygen species (ROS; Mur et al 2005) such as superoxide, hydrogen peroxide, hydroxyl radicals, and singlet oxygen, which may initiate destructive oxidative processes such as chlorophyll bleaching, lipid peroxidation, protein oxidation, and damage to nucleic acids, leading finally to cell death (Lu \& Finkel 2008, Nasir Kham et al. 2010). ROS also have been associated with oxidative changes in plants associated with oxidative damage in the midgut of insects feeding on previously wounded plants (OrozcoCárdenas \& Ryan 1999) or in Spodoptera littoralis feeding on lima bean (Maffei et al. 2006). Wound-induced ROS accumulation, in particular hydrogen peroxide $\left(\mathrm{H}_{2} \mathrm{O}_{2}\right)$, is observed both locally and systemically in leaves of several plant species (Maffei et al. 2006). Being the most stable form of ROS, $\mathrm{H}_{2} \mathrm{O}_{2}$ can move into the cell membrane and initiate oxidative damage in leaf cells, resulting in disruption of metabolic function and loss of cellular integrity. $\mathrm{H}_{2} \mathrm{O}_{2}$ also changes the redox status of the surrounding cells and gives an antioxidative response by acting as a signal of oxidative stress (Hung et al. 2005). Available information suggests that $\mathrm{H}_{2} \mathrm{O}_{2}$ directly regulates the expression of numerous genes, some of which are involved in plant defence and the hypersensitive response, antioxidants, cell rescue/defence proteins and signaling proteins such as kinase, phosphatase and transcription factors (Henry 2008). In general, a plant's direct defence response upon herbivory is characterized by the activation of signalling cascades, which lead to the formation of specific products and physiological changes that interfere with the performance of the herbivore.

To defend themselves against insect attack, plants have evolved elaborate constitutive and inducible defence mechanisms. Constitutive defences are permanent structural or chemical

\footnotetext{
* Author for correspondence: tel +0020101105095 email : gadalla@mans.edu.eg
} 
compounds that occur regardless of the presence of damage and are determined by genetics, environment and former individual life history (Franceschi et al. 2005). For example, plants synthesize different types of antioxidant compounds and activate key antioxidant enzymes such as catalase (CAT; EC 1.11.1.6) and peroxidase (POD; EC 1.11.1.7) (Ni et al. 2001, Zhu et al., 2004); phloem-feeding alfalfa hoppers (Spissistilus festinus L.) increase the activities of several oxidative enzymes and lipid peroxidation of soybean plants (Felton et al. 1994). It has also been reported that herbivory of plants generally stimulated an accumulation of proline and a decrease in total carbohydrate content, while there was no significant effect on the phenolics (Ni et al. 2001). Recent studies have also shown that Nilaparvata lugens infestation reduces the nutrient uptake of rice plants, especially phosphorous and potassium (Wu et al. 2004).

Traditionally, TSSM has been controlled using synthetic chemical acaricides with a level of residuality and permanence that constitute a barrier to the commercialization of agricultural products and cause detrimental effects to environment and human health. If used properly, they can control high populations of TSSM, but its phytophagous nature, high reproductive potential and short life cycle facilitate rapid resistance development to many acaricides often after only a few applications (Anazawa et al. 2003). Currently, great efforts are directed towards reductions in the use of traditional pesticides and increases in the use of Integrated Pest Management (IPM) techniques. One alternative pest control strategy involves the induction of a plant's own resistance mechanisms against pests by the application of elicitors. In recent decades, several plant chemical elicitors such as salicylic acid (SA) and jasmonic acid (JA) and its methyl ester (MeJA) have been used to induce defensive responses equivalent to insect or pathogen attacks (e.g. Hudgins \& Franceschi 2004, Erbilgin et al. 2006). All these substances are endogenous plant phytohormones known to be involved in triggering induced defence responses after insect attack (Halitschke \& Baldwin 2004).

JA and MeJA are one of the simplest of non-traditional plant hormones with diverse roles and functions, including a potential role in plant defence as part of a complex signalling pathway (Cheong \& Choi 2003). In recent years, MeJA has been found not only to regulate a variety of plant-developmental responses, but to be induced by pathogen attack or wounds caused by herbivory that often lead to the generation of reactive oxygen species (Devoto \& Turner 2003) and induced resistance to herbivores (Omer et al. 2001). JA is known to be produced by a plant after caterpillar damage, resulting in increased production of compounds involved in resistance (Thaler et al. 1996), including hydrogen peroxide, superoxide anions and hydroxyl free radicals (Devoto \& Turner 2003). These observations suggest that MeJA could be linked to oxidative stress. The different effects of MeJA on protective-enzyme activities could be associated with $\mathrm{H}_{2} \mathrm{O}_{2}$ metabolism (Ali et al. 2006, Parra-Lobato et al. 2009).

Salicylic acid (SA), a plant phenolic and considered to be a hormone-like endogenous regulator, has been proposed as an endogenous signal associated with regulating oxidant levels in response to biotic stress. Recent studies have shown that SA plays an important role in provoking plant resistance to various biotic and abiotic stresses (Drazic \& Mihailovic 2005, Farouk et al. 2008, Farouk \& Osman 2009). Since the mode of the SA-signalling pathway is associated with increased $\mathrm{H}_{2} \mathrm{O}_{2}$ levels (Chen et al. 1993), it might be expected that SA pretreatment would accentuate the oxidative stress caused by TSSM invasion. Pretreatment with SA protects plants from oxidative damage, and is often associated with an increase in antioxidant enzymes (Daneshmand et al. 2009). Mahdavian et al. (2007) on pepper showed that exogenous application of SA caused significant increases in polyphenol oxidase and peroxidae enzyme activities, but decreased catalase, ascorbate peroxidase and glutathione reductase activities.

The maintenance of membrane integrity is important for enhanced stress tolerance. This is why the role of SA or MeJA on membrane leakage, lipid peroxidation, $\mathrm{H}_{2} \mathrm{O}_{2}$ production and mineral uptake of plants under TSSM invasion is of great importance. Therefore, the induction of plant resistance against herbivores is considered to be a possible potent method in reducing 
and controlling red mite infestion. To our knowledge, however, little is known about the dynamics of the activities of antioxidants under TSSM infestion. The present study was an attempt to carry out an investigation into the effect of SA and MeJA on bean plants under TSSM infestation, with the aim of characterizing variation in antioxidant ability of different concentrations, investigating the possible mechanisms responsible for TSSM tolerance in treated plants treated with SA or MeJA, and elucidating the possible mechanisms that might be involved in the SA- or MeJA-promoted antioxidant responses to TSSM infestation.

\section{Materials \& Methods}

Two field experiments were conducted in the Plant Protection greenhouse of the Faculty of Agriculture in Mansoura University in two successive seasons (2006 and 2007) to study the impact of MeJA and SA on TSSM infestation in common bean (Phaseolus vulgaris) plants, and on inducing plant resistance to TSSM. Seeds of bean cv. Bronco were sown on March 12 and 9 in the two consecutive seasons respectively. Seeds were sown in hills $10 \mathrm{~cm}$ apart on one side of ridges $3 \mathrm{~m}$ long and $60 \mathrm{~cm}$ width. All agricultural practices were carried out according to the recommendation of Ministry of Agriculture, Egypt.

Plants were divided into four treatment groups within a complete randomized-block design consisting of four replicates per treatment. Treatment one consisted of infestation with 50 adult females of $T$. urticae per plant dispersed over the two trifoliate leaves of 15-day-old plants. The second group was infested the same way but then sprayed with one of the following solutions; distilled water, 50 or $100 \mathrm{mg} / 1 \mathrm{SA}$, and $5 \times 10^{-5}$ or $10^{-5} \mathrm{M} \mathrm{MeJA}$, two weeks after the infestation (35, 40 and 45 days after sowing). Spraying was conducted by first spraying the plants with elicitor solution until dripping after adding $1 \%$ tween 20 as a wetting agent. Spraying was repeated i.e. the first time 21, the second 26 and the third 31 days postinfestation. The third group was sprayed the same way as the second treatment group and was then infested with mites after the third spray. The fourth group were uninfested control plants.

All plants were covered with mite-proof mesh bag. At full blooming stage (70 days after sowing) a random sample of five plants from each experimental plot was taken for determining hydrogen peroxide, lipid peroxidation, membrane permeability, ion content, antioxidant enzymes and compounds (catalase, peroxidase, ascorbic acid, proline, soluble carbohydrates, carotenoids, total phenolic compounds) of the bean shoot. Hydrogen peroxide content was determined according to the method of Velikova et al. (2000). Fresh plant materials were homogenized with $0.1 \%(\mathrm{w} / \mathrm{v})$ trichloracetic acid in an ice bath. The homogenate was centrifuged at 10,000 $\mathrm{g}$ for $10 \mathrm{~min}$ and an aliquot from the supernatant mixed with $10 \mathrm{mM}$ potassium phosphate buffer $(\mathrm{pH}$ 7.0) and $1 \mathrm{M} \mathrm{KI}$. The absorbance of the mixture was read at $390 \mathrm{~nm}$. The content of $\mathrm{H}_{2} \mathrm{O}_{2}$ was given based on a standard curve.

Lipid peroxidation was estimated as thiobarbituric-acid-reactive substances. the malondialdehyde content was determined and calculated as $\mu$ moles/g of fresh weight by the method of Shao et al (2005). Leaf samples were homogenized in 5\% (w/v) trichloracetic acid in an ice bath, and centrifuged at $10,000 \mathrm{~g}$ for $10 \mathrm{~min}$ at $4{ }^{0} \mathrm{C}$. An equal volume of thiobarbituric acid in $20 \%$ trichloroacetic acid solution was added and the sample incubated at $95{ }^{\circ} \mathrm{C}$ for $30 \mathrm{~min}$. The reaction was stopped by placing the reaction tubes in an ice bath. The samples were then centrifuged at $10,000 \mathrm{~g}$ for $30 \mathrm{~min}$. The supernatant was removed, absorption read at $532 \mathrm{~nm}$, and the amount of nonspecific absorption at $600 \mathrm{~nm}$ read and subtracted from this value. The amount of malondialdehyde present was calculated from the extinction coefficient of $155 \mathrm{mM}^{-1} \mathrm{~cm}^{-1}$.

Electrolyte leakage percentage measurement was used to assess membrane permeability according to Goncalves et al. (2007), using an Electrical Conductivity Meter (Hanna, UK). Leaf samples were placed in vials containing distilled water and incubated at 
room temperature for $24 \mathrm{~h}$. Electrical conductivity of the resulting solution $\left(\mathrm{EC}_{1}\right)$ was recorded after incubation. Samples were then placed in a boiling water bath for $30 \mathrm{~min}$, cooled to room temperature, and the second reading $\left(\mathrm{EC}_{2}\right)$ determined. The electrolyte leakage percentage was calculated as $\mathrm{EC}_{1} / \mathrm{EC}_{2}$ and expressed as a percentage.

Catalase (CAT) (EC 1.11.1.6) activity was assayed by measuring the rate of disappearance of $\mathrm{H}_{2} \mathrm{O}_{2}$ using the method of Chance \& Maehly (1955). The reaction mixture contained $100 \mathrm{mM}$ phosphate buffer $(\mathrm{pH} 7.4), 30 \mathrm{mM} \mathrm{H}_{2} \mathrm{O}_{2}$ and enzyme extract. The reaction was stopped after $1 \mathrm{~min}$ by adding $10 \mathrm{ml}$ of $2 \% \mathrm{H}_{2} \mathrm{SO}_{4}$. The zero-time activity was carried out by adding $10 \mathrm{ml}$ of $2 \% \mathrm{H}_{2} \mathrm{SO}_{4}$ before the enzyme extract was added to the reaction. The acidified reaction mixtures were titrated with $0.01 \mathrm{~N} \mathrm{KMnO}_{4}$ until a faint pink color persisted for one minute.

Peroxidase (EC 1.11.1.7) activity was assayed by the method of Kumar \& Khan (1982). The reaction mixture used for estimating the peroxidase enzyme contained $0.1 \mathrm{M}$ phosphate buffer ( $\mathrm{pH}$ 6.8), $0.01 \mathrm{M}$ pyrogallol, $0.005 \mathrm{M} \mathrm{H}_{2} \mathrm{O}_{2}$ and the enzyme extract. The solution was incubated for $5 \mathrm{~min}$ at $25{ }^{\circ} \mathrm{C}$ after which the reaction was terminated by adding $2.5 \mathrm{~N} \mathrm{H}_{2} \mathrm{SO}_{4}$. The amount of purpurogallin formed was determined by measuring the absorbance at $420 \mathrm{~nm}$ against a reagent blank prepared by adding the extract after the addition of $2.5 \mathrm{~N} \mathrm{H}_{2} \mathrm{SO}_{4}$ at the zero time.

Ascorbic acid was extracted from plant material and titrated using 2.6- dichlorophenol indophenole, as described by Sadasivam \& Manickam (1996). Total phenolic compounds were determined according to the method of Singleton \& Rossi (1965) using Folin-Ciocalteau reagent. Proline was determined by the method described by Bates et al. (1973). Total soluble carbohydrates were extracted and estimated using the dinitrosalycylic acid method as described by Sadasivam \& Manickam (1996). For the analysis of certain elements, one gram of the ground dry leaves was digested with acid mixture (perchloric and sulphuric acids as described by Chapman \& Pratt (1978)). Total nitrogen content was determined using micro-Kjeldahl methods; potassium using a flame photometer (Kalra 1998), and phosphorous using ammonium molybdate and ascorbic acid (Cooper 1977).

The data were evaluated using one-way ANOVA to compare the effectiveness of elicitors in inducing plant resistance to TSSM. Means were then compared using Duncan's multiple-range test (at $\mathrm{P}=0.05$ ) using COSTAT software.

\section{Results}

One of the expected consequences of TSSM-infestation-induced cellular build-up of reactive oxygen species is an increase in lipid peroxidation. The assay of cellular accumulation of lipid peroxidation products, in the form of thiobarbituric-acid-reactive substances, can provide a comparative indication of such activity. In the present study, the content of thiobarbituric-acidreactive substances and membrane permeability were utilized as biomarkers for lipid peroxidation. Infestation with TSSM induced the accumulation of thiobarbituric-acid-reactive substances in bean shoots, followed by an increase in membrane permeability due to the hyperaccumulation of hydrogen peroxide in the two growing seasons (Table 1). The application of either SA or MeJA, and in particular $100 \mathrm{mg} / \mathrm{l} \mathrm{SA}$, before or after infestation significantly decreased the formation of thiobarbituric-acid-reactive substances and improved membrane permeability compared with control or untreated infested plants. The application of any elicitor significantly increased hydrogen peroxide content over control plants, but decreased it relative to untreated infested plants. 
Table 1: Hydrogen peroxide and lipid peroxidation concentration as well as membrane permeability percentage of 70-day-old bean plants infested with Two-spotted Spider Mite (TSSM) and treated with salicylic acid (SA, at high $[100 \mathrm{mg} / \mathrm{l}]$ or low $[50 \mathrm{mg} / \mathrm{l}]$ levels) or the methyl ester of jasmonic acid (MeJA, at high $\left[5 \times 10^{-5} \mathrm{M}\right]$ or low $\left[10^{-5} \mathrm{M}\right]$ levels).

\begin{tabular}{|c|c|c|c|c|c|c|c|}
\hline \multirow{2}{*}{\multicolumn{2}{|c|}{ Treatment }} & \multicolumn{2}{|c|}{ Hydrogen peroxide } & \multicolumn{2}{|c|}{ Lipid peroxidation } & \multicolumn{2}{|c|}{ Membrane permeability } \\
\hline & & $1^{\text {st }}$ season & $2^{\text {nd }}$ season & $1^{\text {st }}$ season & $2^{\text {nd }}$ season & $1^{\text {st }}$ season & $2^{\text {nd }}$ season \\
\hline \multirow{2}{*}{\multicolumn{2}{|c|}{$\begin{array}{l}\text { Control } \\
\text { TSSM }\end{array}$}} & $15.4 \pm 0.1^{\mathrm{h}}$ & $15.0 \pm 0.3^{\mathrm{g}}$ & $9.2 \pm 0.2^{b}$ & $9.3 \pm 0.2^{b}$ & $81.1 \pm 1.3^{\mathrm{d}}$ & $81.8 \pm 0.8^{\mathrm{bcd}}$ \\
\hline & & $32.0 \pm 0.5^{\mathrm{a}}$ & $31.7 \pm 0.6^{\mathrm{a}}$ & $15.6 \pm 0.5^{\mathrm{a}}$ & $16.8 \pm 0.5^{\mathrm{a}}$ & $90.8 \pm 0.7^{\mathrm{a}}$ & $90.9 \pm 0.3^{\mathrm{a}}$ \\
\hline \multirow{4}{*}{ 兽 } & hig & $21.0 \pm 0.1^{\mathrm{bc}}$ & $21.7 \pm 1.1^{\mathrm{b}}$ & $8.4 \pm 0.1^{\mathrm{cd}}$ & $8.4 \pm 0.1^{\mathrm{c}}$ & $86.3 \pm 0.6^{b c}$ & $86.2 \pm 0.3^{\mathrm{ab}}$ \\
\hline & low & $21.6 \pm 0.2^{\mathrm{b}}$ & $21.3 \pm 0.1^{\mathrm{bc}}$ & $8.7 \pm 0.2^{\mathrm{bc}}$ & $8.6 \pm 0.1^{\mathrm{c}}$ & $87.0 \pm 0.1^{b}$ & $86.2 \pm 0.3^{\mathrm{ab}}$ \\
\hline & & $20.2 \pm 0.2^{\mathrm{cd}}$ & $20.0 \pm 0.1^{\mathrm{cd}}$ & $8.1 \pm 0.03^{\mathrm{cd}}$ & $8.0 \pm 0.1^{\mathrm{cd}}$ & $79.5 \pm 0.7^{\mathrm{d}}$ & $79.5 \pm 0.8^{\mathrm{bcd}}$ \\
\hline & & & $18.8 \pm 0.2^{\mathrm{de}}$ & 7.3 & 6.7 & $0.7^{\mathrm{e}}$ & $76.6 \pm 0.4^{\text {cde }}$ \\
\hline \multirow{4}{*}{ 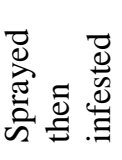 } & high & $18.2 \pm 0.2^{f}$ & $17.8 \pm 0.1^{\mathrm{ef}}$ & $6.3 \pm 0.1^{\mathrm{f}}$ & $6.0 \pm 0.1^{\mathrm{f}}$ & $74.0 \pm 0.4^{\mathrm{f}}$ & $73.9 \pm 0.9^{\mathrm{de}}$ \\
\hline & low MeJA & $19.6 \pm 0.1^{\mathrm{de}}$ & $18.5 \pm 0.9^{\mathrm{de}}$ & $7.8 \pm 0.1^{\mathrm{de}}$ & $7.6 \pm 0.1^{\mathrm{d}}$ & $84.5 \pm 0.5^{\mathrm{c}}$ & $84.2 \pm 0.6^{\mathrm{abc}}$ \\
\hline & low $s$ & $17.4 \pm 0.2^{\mathrm{g}}$ & $17.2 \pm 0.3^{\text {ef }}$ & $5.8 \pm 0.2^{f}$ & $5.4 \pm 0.2^{\mathrm{f}}$ & $71.9 \pm 1.1^{\mathrm{f}}$ & $68.8 \pm 8.2^{\mathrm{e}}$ \\
\hline & high SA & $16.0 \pm 0.3^{\mathrm{h}}$ & $16.3 \pm 0.2^{\mathrm{fg}}$ & $5.0 \pm 0.1^{\mathrm{g}}$ & $4.3 \pm 0.3^{\mathrm{g}}$ & $67.9 \pm 1.0^{\mathrm{g}}$ & $68.6 \pm 1.2^{\mathrm{e}}$ \\
\hline
\end{tabular}

Values are given as mean $\pm \mathrm{SE}$ of three replicates. Means in columns with different letters are significantly different at $\mathrm{P}<0.05$ by Duncan's Multiple Range Test.

Data presented in Table 2 indicate that peroxidase activity significantly increased with either TSSM invasion alone, or the exogenous application of either SA or MeJA after or before infestation. Higher activities were obtained when plants were sprayed with either MeJA or SA before TSSM invasion, with the highest values with $100 \mathrm{mg} / \mathrm{l} \mathrm{SA}$ before TSSM invasion in both growing seasons as compared with control or infested plants. Catalase activity decreased significantly due to TSSM infestation or SA application compared with control plants, but SA and in particular at $100 \mathrm{mg} / \mathrm{l}$ significantly increased activity over TSSM-infested plants. MeJA, and in particular when applied at a level of $10^{-5} \mathrm{M}$ after TSSM infestion, significantly increased catalase activity over control or untreated infested plants.

Table 2: Catalase and peroxidase enzyme activities of 70-day-old bean plant shoots infested with TSSM and treated with SA or MeJA. Abbreviations as Table 1.

\begin{tabular}{|c|c|c|c|c|c|}
\hline \multirow{2}{*}{\multicolumn{2}{|c|}{ Treatment }} & \multirow{2}{*}{$\begin{array}{l}\text { Catalase } \\
1^{\text {st }} \text { season }\end{array}$} & \multicolumn{3}{|c|}{ Peroxidase } \\
\hline & & & $2^{\text {nd }}$ season & $1^{\text {st }}$ season & $2^{\text {nd }}$ season \\
\hline & $54.8 \pm 0.7^{\mathrm{de}}$ & $54.5 \pm 0.8^{\mathrm{d}}$ & $15.5 \pm 0.2^{h}$ & $15.4 \pm 0.7^{h}$ \\
\hline \multicolumn{2}{|l|}{ TSSM } & $34.1 \pm 0.3^{\mathrm{i}}$ & $34.3 \pm 0.6^{\mathrm{h}}$ & $22.2 \pm 0.2^{\mathrm{g}}$ & $21.9 \pm 0.3^{\mathrm{g}}$ \\
\hline \multirow{5}{*}{\multicolumn{2}{|c|}{ 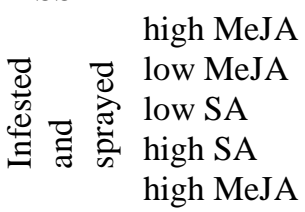 }} & $64.0 \pm 0.7^{\mathrm{b}}$ & $62.0 \pm 0.4^{\mathrm{b}}$ & $24.1 \pm 0.2^{\mathrm{f}}$ & $23.5 \pm 0.2^{\mathrm{f}}$ \\
\hline & & $69.8 \pm 1.1^{\mathrm{a}}$ & $70.0 \pm 1.2^{\mathrm{a}}$ & $23.1 \pm 0.2^{\mathrm{g}}$ & $22.9 \pm 0.2^{\text {fg }}$ \\
\hline & & $43.5 \pm 0.7^{\mathrm{h}}$ & $40.9 \pm 0.8^{\mathrm{g}}$ & $26.3 \pm 0.1^{\mathrm{de}}$ & $25.8 \pm 0.2^{\mathrm{e}}$ \\
\hline & & $46.6 \pm 0.7^{g}$ & $46.5 \pm 1.0^{\mathrm{f}}$ & $28.8 \pm 0.5^{\mathrm{c}}$ & $28.6 \pm 0.3^{\mathrm{c}}$ \\
\hline & & $57.0 \pm 0.4^{\mathrm{d}}$ & $56.7 \pm 0.6^{\mathrm{c}}$ & $27.1 \pm 0.3^{\mathrm{d}}$ & $27.2 \pm 0.2^{\mathrm{d}}$ \\
\hline \multirow{3}{*}{ 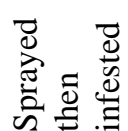 } & low MeJA & $59.5 \pm 0.6^{\mathrm{c}}$ & $58.5 \pm 0.3^{\mathrm{c}}$ & $25.5 \pm 0.2^{\mathrm{e}}$ & $25.1 \pm 0.03^{\mathrm{e}}$ \\
\hline & low SA & $51.0 \pm 1.4^{\mathrm{f}}$ & $50.1 \pm 0.9^{\mathrm{e}}$ & $31.5 \pm 0.6^{b}$ & $30.9 \pm 0.7^{\mathrm{b}}$ \\
\hline & high SA & $53.4 \pm 0.4^{\mathrm{e}}$ & $52.1 \pm 0.2^{\mathrm{e}}$ & $34.4 \pm 0.3^{\mathrm{a}}$ & $34.3 \pm 0.5^{\mathrm{a}}$ \\
\hline
\end{tabular}

Values are given as mean \pm SE of three replicates. Means in columns with different letters are significantly different at $\mathrm{P}<0.05$ by Duncan's Multiple Range Test. 
Table 3: Ascorbic acid, soluble sugars, total soluble phenol, proline and total carotenoids of 70day-old common bean plants infested with TSSM and treated with SA or MeJA in both growing seasons. Abbreviations as in Table 1.

\begin{tabular}{|c|c|c|c|c|c|c|c|c|c|c|c|}
\hline \multirow{2}{*}{ Treatmen } & & \multicolumn{2}{|c|}{ Ascorbic acid } & \multicolumn{2}{|c|}{ Soluble carbohydrates } & \multicolumn{2}{|c|}{ Total soluble phenol } & \multicolumn{2}{|l|}{ Proline } & \multicolumn{2}{|c|}{ Total carotenoids } \\
\hline & & $1^{\text {st }}$ season & $2^{\text {nd }}$ season & $1^{\text {st }}$ season & $2^{\text {nd }}$ season & $1^{\text {st }}$ season & $2^{\text {nd }}$ season & $1^{\text {st }}$ season & $2^{\text {nd }}$ season & $1^{\text {st }}$ season & $2^{\text {nd }}$ season \\
\hline \multicolumn{2}{|l|}{ Control } & $15.7 \pm 0.4^{\mathrm{e}}$ & $15.9 \pm 0.2^{\mathrm{e}}$ & $29.2 \pm 2.6^{\mathrm{h}}$ & $27.3 \pm 2.0^{\mathrm{h}}$ & $11.3 \pm 0.1^{\mathrm{h}}$ & $11.4 \pm 0.4^{\mathrm{h}}$ & $11.6 \pm 0.5^{\mathrm{h}}$ & $15.0 \pm 0.3^{\mathrm{h}}$ & $0.53 \pm 0.01^{\mathrm{h}}$ & $0.52 \pm 0.01^{\mathrm{g}}$ \\
\hline \multicolumn{2}{|l|}{ TSSM } & $9.3 \pm 0.2^{\mathrm{f}}$ & $9.4 \pm 0.9^{\mathrm{f}}$ & $36.2 \pm 0.6^{\mathrm{g}}$ & $36.2 \pm 1.2^{\mathrm{g}}$ & $21.3 \pm 0.2^{\mathrm{g}}$ & $20.9 \pm 0.1^{\mathrm{g}}$ & $19.6 \pm 0.3^{\mathrm{g}}$ & $31.7 \pm 0.6^{\mathrm{g}}$ & $0.40 \pm 0.002^{\mathrm{i}}$ & $0.39 \pm 0.002^{\mathrm{h}}$ \\
\hline \multirow{5}{*}{ 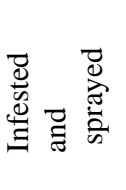 } & high & $3.1 \pm 0.6^{\mathrm{d}}$ & $18.1 \pm 0.6^{\mathrm{d}}$ & $48.0 \pm 1.0^{\mathrm{e}}$ & $46.5 \pm 0.8^{\mathrm{e}}$ & $23.9 \pm 0.6^{\mathrm{f}}$ & $23.4 \pm 0.4^{\mathrm{f}}$ & $22.0 \pm 0.2^{\mathrm{e}}$ & $21.7 \pm 1.1^{\mathrm{e}}$ & $0.71 \pm 0.005^{\mathrm{f}}$ & $0.70 \pm 0.01^{\mathrm{e}}$ \\
\hline & low MeJA & & $17.4 \pm 0.3^{\mathrm{de}}$ & $43.0 \pm 0.8^{f}$ & $42.7 \pm 1.0^{\mathrm{f}}$ & $22.1 \pm 0.4^{\mathrm{fg}}$ & $22.7 \pm 0.3^{\mathrm{fg}}$ & $20.6 \pm 0.1^{\mathrm{f}}$ & $0.1^{\mathrm{f}}$ & 0.65 & $0.64 \pm 0.01^{\mathrm{f}}$ \\
\hline & low SA & $19.1 \pm 0.4^{\mathrm{d}}$ & $19.1 \pm 0.4^{\mathrm{d}}$ & $50.9 \pm 0.5^{\mathrm{de}}$ & $50.1 \pm 0.3^{\mathrm{d}}$ & $27.9 \pm 0.6^{\mathrm{e}}$ & $27.3 \pm 0.3^{\mathrm{e}}$ & $23.3 \pm 0.1^{\mathrm{d}}$ & $20.0 \pm 0.1^{\mathrm{d}}$ & $0.74 \pm 0.01^{\mathrm{ef}}$ & $0.73 \pm 0.01^{\mathrm{de}}$ \\
\hline & high SA & $22.6 \pm 0.1^{\mathrm{b}}$ & $22.2 \pm 0.5^{b c}$ & $56.6 \pm 0.8^{\mathrm{c}}$ & $55.8 \pm 0.8^{\mathrm{c}}$ & $36.7 \pm 1.1^{\mathrm{c}}$ & $36.4 \pm 1.2^{\mathrm{c}}$ & $24.5 \pm 0.3^{c}$ & $18.8 \pm 0.2^{\mathrm{c}}$ & $0.87 \pm 0.00^{c}$ & $0.86 \pm 0.002^{b}$ \\
\hline & JA & $20.8 \pm 0.3^{\mathrm{c}}$ & $20.8 \pm 0.6$ & $60.7 \pm 0.6^{\mathrm{b}}$ & $59.9 \pm 0.6^{\mathrm{b}}$ & $34.6 \pm 0.2^{\mathrm{d}}$ & $32.9 \pm 1.5^{\mathrm{d}}$ & $25.2 \pm 0.2^{c}$ & $17.8 \pm 0.1^{\mathrm{c}}$ & $0.83 \pm 0.01^{\mathrm{cd}}$ & $0.82 \pm 0.01^{\mathrm{bc}}$ \\
\hline \multirow{3}{*}{ 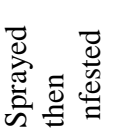 } & low MeJA & $18.9 \pm 0.4^{\mathrm{d}}$ & $19.2 \pm 0.3^{\mathrm{d}}$ & $53.7 \pm 0.9^{\mathrm{cd}}$ & $52.9 \pm 0.7^{\mathrm{cd}}$ & $26.3 \pm 0.4^{\mathrm{e}}$ & $26.1 \pm 0.6^{\mathrm{e}}$ & $23.8 \pm 0.1^{\mathrm{d}}$ & $18.5 \pm 0.9^{\mathrm{d}}$ & $0.79 \pm 0.01^{\mathrm{de}}$ & $0.78 \pm 0.01^{\mathrm{cd}}$ \\
\hline & low SA & $24.1 \pm 0.5^{\mathrm{b}}$ & $22.9 \pm 0.6^{\mathrm{b}}$ & $63.6 \pm 1.2^{\mathrm{b}}$ & $62.8 \pm 0.8^{b}$ & $42.1 \pm 0.8^{b}$ & $41.9 \pm 0.6^{\mathrm{b}}$ & $26.7 \pm 0.2^{\mathrm{b}}$ & $17.2 \pm 0.3^{b}$ & $1.09 \pm 0.01^{\mathrm{a}}$ & $1.03 \pm 0.02^{\mathrm{a}}$ \\
\hline & high SA & $27.7 \pm 1.3^{\mathrm{a}}$ & $26.1 \pm 0.7^{\mathrm{a}}$ & $67.3 \pm 0.8^{\mathrm{a}}$ & $66.9 \pm 0.6^{\mathrm{a}}$ & $46.5 \pm 1.1^{\mathrm{a}}$ & $46.1 \pm 0.2^{\mathrm{a}}$ & $27.9 \pm 0.2^{\mathrm{a}}$ & $16.3 \pm 0.2^{\mathrm{a}}$ & $1.03 \pm 0.05^{\mathrm{b}}$ & $0.99 \pm 0.04^{\mathrm{a}}$ \\
\hline
\end{tabular}

Values are given as mean \pm SE of three replicates. Means in columns with different letters are significantly different at $\mathrm{P}<0.05$ by Duncan's Multiple Range Test.

The pattern of changes in antioxidant compounds is presented in Table 3. Plants infested with TSSM had the minimum concentrations of ascorbic acid and total carotenoids but significantly increased concentrations of soluble carbohydrates, total soluble phenol and proline concentration compared with control plants in both growing seasons. The application of both elicitors at both concentrations used, in particular $100 \mathrm{mg} / \mathrm{l} \mathrm{SA}$, increased significantly the concentrations of several antioxidant compounds, i.e. ascorbic acid, soluble carbohydrates, total soluble phenol, proline and carotenoids, compared with control or untreated infested plants. Higher antioxidant concentrations were obtained from applying SA at $100 \mathrm{mg} / \mathrm{l}$ before infestation (Table 3). The application of SA was more effective than MeJA in increasing antioxidant concentrations.

There were significant decreases in the percentage of nitrogen, phosphorous and potassium of TSSM-infested bean shoots as compared with healthy control plants (Table 4). The application of both elicitors before or after TSSM infestation significantly increased the percentage of nitrogen, phosphorous and potassium as compared with healthy or untreated infested plants in both growing saesons. Again SA was more effective than MeJA. The highest values were obtained from the application of $100 \mathrm{mg} / \mathrm{l} \mathrm{SA}$ before TSSM infestation, with the second-highest value from $50 \mathrm{mg} / \mathrm{l} \mathrm{SA}$.

Table 4: Nitrogen, phosphorous and potassium percentages in 70-day-old bean plant shoots infested with TSSM and treated with SA or MeJA. Abbreviations as in Table 1.

\begin{tabular}{|c|c|c|c|c|c|c|c|}
\hline \multirow{2}{*}{\multicolumn{2}{|c|}{ Treatment }} & \multicolumn{2}{|l|}{ Nitrogen } & \multicolumn{2}{|l|}{ Phosphorous } & \multicolumn{2}{|l|}{ Potassium } \\
\hline & & $1^{\text {st }}$ season & $2^{\text {nd }}$ season & $1^{\text {st }}$ season & $2^{\text {nd }}$ season & $1^{\text {st }}$ season & $2^{\text {nd }}$ season \\
\hline Control & & $3.08 \pm 0.04^{\mathrm{f}}$ & $3.06 \pm 0.06^{\mathrm{g}}$ & $0.36 \pm 0.01^{\mathrm{h}}$ & $0.35 \pm 0.02^{\mathrm{g}}$ & $0.86 \pm 0.06^{\mathrm{g}}$ & $0.83 \pm 0.06^{\mathrm{f}}$ \\
\hline \multirow[t]{2}{*}{ TSSM } & & $2.73 \pm 0.11^{\mathrm{g}}$ & $2.73 \pm 0.11^{\mathrm{h}}$ & $0.25 \pm 0.04^{\mathrm{i}}$ & $0.24 \pm 0.04^{\mathrm{h}}$ & $0.67 \pm 0.02^{\mathrm{h}}$ & $0.64 \pm 0.05^{\mathrm{g}}$ \\
\hline & high MeJA & $3.38 \pm 0.06^{\mathrm{e}}$ & $3.38 \pm 0.08^{\mathrm{ef}}$ & $0.44 \pm 0.002^{\mathrm{fg}}$ & $0.43 \pm 0.01^{\mathrm{ef}}$ & $1.07 \pm 0.01^{\mathrm{ef}}$ & $1.07 \pm 0.02^{\mathrm{de}}$ \\
\hline \multirow{4}{*}{ 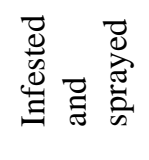 } & low MeJA & $3.15 \pm 0.04^{f}$ & $3.15 \pm 0.04^{\mathrm{fg}}$ & $0.40 \pm 0.01^{\mathrm{gh}}$ & $0.40 \pm 0.01^{\mathrm{fg}}$ & $1.00 \pm 0.02^{\mathrm{f}}$ & $0.98 \pm 0.02^{\mathrm{e}}$ \\
\hline & low SA & $3.59 \pm 0.09^{\mathrm{d}}$ & $3.50 \pm 0.12^{\mathrm{e}}$ & $0.47 \pm 0.01^{\mathrm{ef}}$ & $0.46 \pm 0.01^{\mathrm{de}}$ & $1.14 \pm 0.02^{\mathrm{e}}$ & $1.13 \pm 0.02^{\mathrm{d}}$ \\
\hline & high SA & $4.11 \pm 0.06^{\mathrm{c}}$ & $4.08 \pm 0.08^{\mathrm{c}}$ & $0.54 \pm 0.01^{\mathrm{cd}}$ & $0.52 \pm 0.005^{\mathrm{cd}}$ & $1.39 \pm 0.02^{\mathrm{c}}$ & $1.37 \pm 0.00^{\mathrm{c}}$ \\
\hline & high MeJA & $4.29 \pm 0.06^{\mathrm{bc}}$ & $4.25 \pm 0.06^{\mathrm{bc}}$ & $0.57 \pm 0.02^{c}$ & $0.58 \pm 0.01^{\mathrm{bc}}$ & $1.50 \pm 0.01^{\mathrm{b}}$ & $1.49 \pm 0.01^{\mathrm{b}}$ \\
\hline \multirow{3}{*}{ 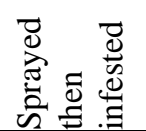 } & low MeJA & $3.76 \pm 0.08^{\mathrm{d}}$ & $3.76 \pm 0.06^{\mathrm{d}}$ & $0.49 \pm 0.01^{\mathrm{de}}$ & $0.50 \pm 0.01^{\mathrm{d}}$ & $1.27 \pm 0.03^{\mathrm{d}}$ & $1.28 \pm 0.03^{\mathrm{c}}$ \\
\hline & low SA & $4.48 \pm 0.04^{\mathrm{b}}$ & $4.43 \pm 0.08^{\mathrm{b}}$ & $0.63 \pm 0.004^{b}$ & $0.62 \pm 0.004^{b}$ & $1.55 \pm 0.01^{\mathrm{b}}$ & $1.55 \pm 0.01^{\mathrm{b}}$ \\
\hline & high SA & $4.74 \pm 0.05^{\mathrm{a}}$ & $4.76 \pm 0.07^{\mathrm{a}}$ & $0.69 \pm 0.02^{\mathrm{a}}$ & $0.71 \pm 0.04^{\mathrm{a}}$ & $1.69 \pm 0.02^{\mathrm{a}}$ & $1.69 \pm 0.03^{\mathrm{a}}$ \\
\hline
\end{tabular}




\section{Discussion}

In response to attack, plants mount a broad range of defence responses, including the generation of ROS (Leitner et al. 2005), comprising radicals and other non-radicals: among these, much attention has been focused on hydrogen peroxide (Grant \& Loake 2000), which is extremely reactive and can oxidize biological molecules, causing oxidative stress (Van Breusegem et al. 2001). Production and removal of ROS are strictly controlled under normal biotic stresses, but when higher plants are subjected to TSSM infestation, the equilibrium between production and scavenging of ROS is broken, resulting in oxidative damage to proteins, DNA and lipids (Mittler 2002). Lipid peroxidation measured as the amount of thiobarbituric-acid-reactive substances or malondialdehyde is produced when polyunsaturated fatty acids in the membrane undergo oxidation by the accumulation of free oxygen radicals. Bi $\&$ Felton (1995) have proposed that herbivore attacks can cause localized oxidative responses in soybean leaves and have identified some potential functions of ROS that might affect plantherbivores interaction. Increases in malondialdehyde and $\mathrm{H}_{2} \mathrm{O}_{2}$ levels, and the rapid degradation of chlorophyll, were observed in bean plants infested with TSSM (Farouk \& Osman, 2009, Table 1), suggesting that the observed plant-growth inhibition and yield reduction must be directly or indirectly attributable to TSSM-infestation-induced oxidative damage.

The reactive nature of ROS makes them potentially harmful to cellular components. Fortunately, plants have the capacity to cope by eliminating them with an efficient ROSscavenging system. Jiang et al. (1994) demonstrated antioxidant enzymes such as superoxidase dismutase and catalase are directly involved in ROS scavenging and plant protection against ROS damage. After TSSM infection the plant can efficiently scavenge the ROS by this antioxidant defence system without any detectable effects on plant growth and yield. However, during some time periods, the scavenging system may become saturated by the increased rate of radical production, and ultimately the excessive levels of ROS result in severe cellular damage or trigger a genetically controlled cell-death program or decreased plant growth and yield (Van Breusegem et al. 2001, Farouk \& Osman 2009). There are reports in this and other investigations that TSSM and other pest infestations increase the content of $\mathrm{H}_{2} \mathrm{O}_{2}$ and peroxidation of the lipid membrane, thus disrupting its permeability, or induce oxidative stress in plant tissues followed by increasing electrolyte leakage and decreasing ion percentage due to the inhibition of $\mathrm{H}_{2} \mathrm{O}_{2}$-scavenging enzymes, in particular catalase (Table 2). Decreased catalase activity in infested plants might promote $\mathrm{H}_{2} \mathrm{O}_{2}$ accumulation, which could result in a HaberWeiss reaction to form hydroxyl radicals. Since $\mathrm{OH}$ radicals are known to damage biological membranes and react with most compounds present in biological systems, they might hasten lipid peroxidation and membrane damage in infested plants. However, the levels of ROS and the extent of oxidative damage depend largely upon the whole antioxidant defence system and the co-operation or coordination among ROS-scavenging enzymes (Liang et al. 2003). It is well known that TSSM infestation decreases nitrogen, phosphorous and magnesium, as found in our investigation. These reductions may be due to reductions in their uptake and/or drain of phloem sap by TSSM. Another study has shown that Nilaparvata lugens infestation reduced the nutrient uptake of rice plants, particularly phosphorous (Wu et al. 2004).

Induced resistance to herbivores is observed in many crop plants in the laboratory and field (Creelman et al. 1992, Inbar et al. 1999). In recent years, elicitors (i.e. MeJA or SA) have been found not only to regulate a variety of plant-developmental responses, but also to be involved in regulating diverse plant functions, including induced resistance to herbivores (Thaler et al. 1999, Omer et al. 2001). JA or SA is produced by the plant after caterpillar damage and results in increased production of compounds involved in resistance (Thaler et al. 1996), including hydrogen peroxide, superoxide anions and hydroxyl free radicals (Devoto \& Turner 2003). These observations suggest that either SA or MeJA could be linked to the 
oxidative burst responsible for cell death in the hypersensitive response after pathogen or pest attack, and could act as a secondary signal for the development of systemic acquired resistance (Shirasu et al. 1997). Pretreatment with elicitors protects plants from oxidative damage caused by these stresses, and is often associated with an increase in antioxidant enzymes (Table 2, Daneshmand et al. 2009, Parra-Lobato et al. 2009).

MeJA is an important cellular regulator involved in diverse developmental processes, such as shoot growth, yield and seed quality (Farouk \& Osman 2009). In addition, jasmonates activate plant defence mechanisms in response to insect-driven wounding, various pathogens, and environmental stress (Cheong \& Choi 2003). In accordance with these results, induction of oxidative stress has been observed in plants exposed to MeJA (Ali et al. 2006, Sarosh \& Meijer 2007). Recently, in Arabidopsis thaliana, the expression of oxidative stress-tolerance genes, including those for peroxidases and oxidases, was also up-regulated by MeJA treatment (Jung et al. 2007). However, it has been proposed that these molecules act as secondary messengers in systemic acquired resistance systems, in analogy to the systemic response induced by wounding (Ryan 1992). Reports on the induction of a resistant state in plants by MeJA are contradictory. Different effects of MeJA on protective enzyme activities could be associated with $\mathrm{H}_{2} \mathrm{O}_{2}$ metabolism (Ali et al. 2006). MeJA may be a suitable candidate for insect control in agriculture. No negative effects on crop yield (Farouk \& Osman 2009) have been found, and plant resistance is enhanced both by directly killing herbivores and by enhancing the action of natural enemies of herbivores (Thaler 1999).

SA is an important signal molecule in plant defence. The mode of SA was proposed to be inhibition of catalase activity and increase in $\mathrm{H}_{2} \mathrm{O}_{2}$ levels during plant-pathogen interactions (Chen et al. 1993). In the present study, pretreatment with SA alone specifically inhibited catalase activity (Table 2) and increased $\mathrm{H}_{2} \mathrm{O}_{2}$ levels (Table 1) in bean shoots. SA can also act as an inhibitor of a step in the biosynthesis of jasmonic acid, a compound involved in woundinduced gene expression (Pena-Cortes et al. 1993). It remains to be seen whether these actions are of direct relevance for systemic acquired resistance. Moreover, as indicated from the present investigation, application of SA significantly increased peroxidase activity, which destroys hydrogen peroxides, leading to decreasing malondialdehyde, and improved membrane permeability. These results are similar to those of Daneshmand et al. (2009). Besides inhibition of catalase, SA-blocked electron flow from substrate dehydrogenisation to the ubiquinone pool in mitochondria might also be an important mechanism of triggering $\mathrm{H}_{2} \mathrm{O}_{2}$ generation (Norman et al. 2004). Several reports, however, show that $\mathrm{H}_{2} \mathrm{O}_{2}$ is unlikely to be a second messenger for SA (Neuenschwander et al. 1995). In the present study, SA treatments lowered the electrolyte leakage in TSSM-stressed plants (Table 1), concordant with Stevens et al. (2006) in the case of tomato, and Yildirim et al. (2008) regarding cucumber, who reported that SA facilitated the maintenance of membrane functions. This may be attributed to the production of antioxidant compounds and enzymes that protect the plant from oxidative damage (El-Tayeb 2005).

In plants, peroxidases are a class of proteins with a large variety of functions. They may be part of the defence system against herbivory (Trevisan et al. 2003), they may catalyze for instance the final polymerization step of lignin synthesis, produce hydrogen peroxide or other phenoxy radicals such as phenole that may directly deter feeding by insect herbivores, and/or produce toxins that reduce plant digestibility (Felton 1989). The present investigation showed that application of either SA or MeJA after or before TSSM infestation significantly increased peroxidase activity as compared with control or unsprayed infested plants. Our results agree with those of Mahdavian et al. (2007) and Daneshmand et al. (2009) who indicated that application of SA increased peroxidase activities in plant tissues. This increase may be attributed to increased activity of peroxidase-encoding genes or increased activation of already existing enzymes, as suggested by Dionisio-Sese \& Tobita (1998). In the literature, only one work about the induction of peroxidase by exogenous MeJA was found (Garrido et al. 2003), stimulating $\mathrm{O}_{2}{ }^{--}$synthesis by root cells. 
As indicated from our results and other investigations, catalase levels decreased significantly following herbivory by $H$. zea (Bi \& Felton 1995) and TSSM, or following exogenous application of SA. Several reports have shown that SA at high concentrations (1 $\mathrm{mM}$ ) can bind to and inhibit several heme-containing enzymes such as catalase, ascorbate peroxidase, or aconitase by virtue of its affinity for iron (Ruffer et al. 1995). In the present case, a significant decrease in catalase activity was found in bean leaves in the absence of TSSM (Table 2), while SA modulated catalase activity back to the range of the untreated control in the presence of TSSM. Similar to these results, addition of $0.5 \mathrm{mM}$ SA to hydroponic cultures for $24 \mathrm{hr}$ decreased catalase activity in maize plants (Janda et al. 1999). Although decreased catalase activity was observed in the results of the TSSM infestation, increased catalase activity (Table 2) was observed in the MeJA treatments, showing higher capacity for the decomposition of $\mathrm{H}_{2} \mathrm{O}_{2}$ generated. Since enzymes involved in antioxidant metabolism are usually co-regulated and their activities increase upon exposure to stress, higher activity levels in bean shoots indicate increased oxidative stress upon MeJA exposure. The observations also strongly imply a possibility that enzymatic antioxidant systems are also utilized in bean to alleviate oxidative stress caused by MeJA, thus protecting the cells from oxidative damage. Recently, Parra-Lobato et al. (2009) indicated that catalase activity of homogenates was higher after $30 \mathrm{~min}$ in MeJA-treated sunflower roots.

Application of both elicitors increased antioxidant compounds such as ascorbic acid, phenols, proline, carotenoids and soluble carbohydrates which counteracted the harmful effects of ROS on the plants. These results are consistent with the role of both SA and MeJA in defensive responses that have been extensively studied in other plants. SA and MeJA have been reported to induce anatomical and chemical changes such as the increasing synthesis of phenolics in many plants (Zeneli et al. 2006, Raju et al. 2008). This accumulation may be due to the induction of phenyl amino layase gene expression and synthesis of phenolic compounds (Raju et al. 2008). Yet total phenols have long been considered as important defence-related compounds whose levels are naturally high in resistant varieties of many crops (Gogoi et al. 2001). In this concern Raju et al (2008) found that in some plants application of SA increased phenol content due to the activation of the phenyl amino layase enzyme.

Of the antioxidants found in plants, ascorbic acid is the most abundant and has diverse physiological roles, being a substrate for ascobate peroxidase in addition to directly scavenging superoxide, hydroxyl radicals, and singlet oxygen: it is therefore an antiherbivory agent (Smirnoff et al. 2001). In fact, a high level of endogenous ascorbate is essential to maintain the antioxidant system that protects plant from oxidative damage due to biotic and abiotic stresses (Chen et al. 2007).

Proline is another important component of the defence system of plants to counter stress. It has been previously shown that proline levels increase in bean leaves in reponse to TSSM infestation or elicitor application before or after infestation. Our result corroborates those of El-Tayeb (2005), who claimed that proline could be considered an important component in the spectrum of SA-induced protective reactions of plants against salinity stress. These results are consistent with the proposal of Khattab (2005) that showed the increased proline content of eucalyptus leaves infested with xylem-feeding insects. Proline is capable of movement between tissues, and is believed to protect plant against stress by acting as a storage compound for both carbon and nitrogen sources, thus protect cytoplasmic enzymes and cellular structure (Serrano \& Gaxiola 1994). Additional roles for proline such as ROS detoxification and stabilization of cell membranes have been proposed (Kavir Kishor et al. 2005).

Previous research has shown that most herbivorous insects use carbohydrates as feeding stimulants (Blaney \& Simmonds 1988) and as important nutrients needed to synthesize body tissue and serve as energy sources (Schoonhoven et al. 1998). Derridj et al. (1989) reported that sugars have also been shown to promote oviposition in some species. Carbohydrates may directly affect mite level damage via changes in the nutritional quality of 
bean plants. Such effects might be due to the drain of assimilates towards the insect and/or decreases in their biosynthetic pathways induced by TSSM. A strong and persistent flow of host assimilates is created by the continual removal of metabolites and breakdown of insoluble reserves by insects (Khattab 2005). The phloem-feeding TSSM continually controls and/or modifies the levels of metabolic substances in the surrounding tissues. This is supported in the current work where the levels of total soluble carbohydrates of infested bean leaves were lower than those of healthy ones (Table 3).

Results also showed that the application of both elicitors, in particular SA, increased significantly the ion content $(\mathrm{N}, \mathrm{P}, \mathrm{K})$ in bean shoots, reflecting increasing plant growth and induced resistance to pests due to their role in plant metabolism, such as promoting the development of thicker outer walls and the stability of plant membranes in epidermal cells, thus preventing pest attack (Marschner 1986). Increasing nitrogen in plants stimulates the synthesis of phenols and lignin, all parts of the defence system against infestation (Marschner 1986). Earlier studies indicated that exogenous SA treatments stimulated root formation and increased mineral uptake by plants (Khan et al. 2003, Yildirim et al. 2008).

In conclusion, foliar application of both elicitors, particularly SA, enhanced enzymatic and non-enzymatic antioxidants in bean shoots infested by TSSM, thus suppressing invasioninduced oxidative damage and enhancing tolerance. Current knowledge limits the complete description of elicitor signal-transduction pathways in plants: future studies are needed to dissect the complex network of elicitors and its involvement in plant defence against biotic and abiotic stresses, using genetic, genomic and biochemical approaches.

Acknowledgements

We are grateful to Prof Dr. I. Fedina (Bulgaria) for providing methyl jasmonate.

\section{References}

Ali MB, Yu KW, Hahn EJ \& Paek KY (2006) Methyl jasmonate and salicylic acid elicitation induces ginsenoside accumulation, enzymatic and non-enzymatic antioxidant in suspension culture of Panax ginseng roots in bioreactors. Plant Cell Reports 25: 613-620.

Anazawa Y, Tomita T, Aiki Y, Kozaki T\& Kono Y (2003) Sequence of a cDNA-encoding acetylcholinesterase from susceptible and resistant two-spotted spider mite, Tetranychus urticae. Insect Biochemistry \& Molecular Biology 33: 509-514.

Bates LS, Waldren RP \& Teare ID (1973) Rapid determination of free proline for water-stress studies. Plant \& Soil 39: 205-207.

Bi JL \& Felton GW (1995) Foliar oxidative stress and insect herbivory: primary compounds, secondary metabolites and reactive oxygen species as components of induced resistance. Journal of Chemical Ecology 21: 1511-1530

Blaney WM \& Simmonds MJS (1988) Food selection in adults and larvae of three species of Lepidoptera: a behavioural and electrophysiological study. Entomologia Experimentalis \& Applicata 49: 111-121.

Chance B \& Maehly AC (1955) Assay of catalase and peroxidase. Methods in Enzymology 2:764-775

Chapman HO \& Pratt PE (1978) Methods of analysis for soils, plants and water. University of California Agricultural Science Publication 4034: 50-169.

Chen ZX, Silva H \& Klessig DF (1993) Active oxygen species in the induction of plant systemic acquired resistance by salicylic acid. Science 262: 1883-1885

Chen KM, Gong HJ, Wang SM \& Zhang CL (2007) Antioxidant defence system in Phragmites communis Trin. ecotypes. Biologia Plantarum 51(4): 754-758.

Cheong JJ \& Choi YD (2003) Methyl jasmonate as a vital substance in plants. Trends in Genetics 19: 409-413.

Cooper TG (1977) The tools of biochemistry. A Wiley-Interscience Pub. John Wiley and Sons, New York.

Creelman RA, Tierney ML \& Mullet JE (1992) Jasmonic acid/methyl jasmonate accumulate in wounded soybean hypocotyls and modulate wound gene expression. Proceedings of the National Academy of Science USA, 89: 4938-4941.

Daneshmand F, Arvin MJ \& Kalantar KM (2009). Effect of acetylsalicylic acid (Aspirin) on salt and osmotic stress tolerance in Solanum bulbocastanum in vitro: enzymatic antioxidants. American-Eurasian Journal of Agricultural \& Environmental Science 6 (1): 92-99. 
Derridj S, Gregoire V, Boutin JP \& Fiala V (1989) Plant growth stages in the interspecific oviposition preference of the European corn borer and relation with chemicals present on the leaf surface. Entomologia Experimentalis \& Applicata 53: 267-276.

Devoto A \& Turner JG (2003) Regulation of jasmonate-mediated plant responses in Arabidopsis. Annals of Botany 92:329-337.

Dionisio-Sese ML, Tobita S (1998) Antioxidant responses of rice seedlings to salinity stress. Plant Science 135: $1-9$.

Drazic G \& Mihailovic N (2005) Modification of cadmium toxicity in soybean seedlings by salicylic acid. Plant Science 168:511-517.

El-Tayeb MA (2005) Response of barley grains to the interactive effect of salinity and salicylic acid. Plant Growth Regulation 45:215-224.

Erbilgin N, Krokene P, Christiansen E, Zeneli G \& Gershenzon J (2006) Exogenous application of methyl jasmonate elicits defences in Norway spruce (Picea abies) and reduces host colonization by the bark beetle Ips typographus. Oecologia 148:426-436.

Farouk S \& Osman MA (2009) Induction of resistance in common bean plants Phaseolus vulgaris L. using different plant elicitors against spider mite Tetranychus urticae Koch infestation. Journal of Agricultural Science, Mansoura University 34 (12):11399- 11419.

Farouk S, Ghoneem KM \& Abeer A Ali (2008). Induction and expression of systematic resistance to downy mildew disease in cucumber plant by elicitors. Egyptian Journal of Phytopathology 1-2: 95-111.

Felton GW, Donato K, Del Vecchio RJ \& Duffey SS (1989) Activation of plant foliar oxidases by insect feeding reduces nutritive quality of foliage for noctuid herbivores. Journal of Chemical Ecology 15: 2667-2694

Felton GW, Summers CB \& Muller AJ (1994) Oxidative responses in soybean foliage to herbivory by bean leaf beetle and three cornered alfalfa leafhopper. Journal of Chemical Ecology 20: 639-650.

Franceschi V, Krokene P, Christiansen E \& Krekling T 3 (2005) Anatomical and chemical defences of conifer bark against bark beetles and other pests. New Phytologist 167: 353-376.

Garrido I, Espinosa F, Cordoba-Pedregosa MC, Gonzalez-Reyes JA, Alvarez-Tinaut MC (2003) Redox-related peroxidative responses evoked by methyljasmonate in axenically cultured aeroponic sunflower (Helianthus annuus L.) seedling roots. Protoplasma 221: 79-91.

Gogoi R, Singh DV \& Srivastava KD (2001) Phenols as a biochemical basis of resistance in wheat against karnal bunt. Plant Pathology 50(4):470-476.

Goncalves JF, Becker AG, Cargnelutti D, Tabaldi LA, Pereira LB, Battisti V, Spanevello RM, Morsch VM, Nicoloso FT, Schetinger MRC (2007). Cadmium toxicity causes oxidative sress and induces response of the antioxidant system in cucumber seedlings. Brazilian Journal of Plant Physiology 19(3): 223-232.

Grant JJ \& Loake GJ (2000) Role of reactive oxygen intermediate and cognate redox signaling in disease resistance. Plant Physiology 124:21-29

Halitschke R \& Baldwin IT (2004) Jasmonates and related compounds in plant-insect interactions. Journal of Plant Growth Regulation 23: 238-245.

Henry JF (2008) Use and abuse of exogenous $\mathrm{H}_{2} \mathrm{O}_{2}$ in studies of signal transduction. Free Radicals in Biology \& Medicine 42(7): 926-932.

Hudgins JW \& Franceschi VR (2004) Methyl jasmonate-induced ethylene production is responsible for conifer phloem defence responses and reprogramming of stem cambial zone for traumatic resin duct formation. Plant Physiology 135:2134-2149.

Hung SH, Yu CW \& Lin CH (2005) Hydrogen peroxide functions as a stress signal in plants. Botanical Bulletin of the Academia Sinica 46: 1-10

Inbar M, Doostdar H, Leibee GL \& Mayer RT (1999) The role of plant rapidly induced responses in asymmetric interspecific interactions among insect herbivores. Journal of Chemical Ecology 25: 1961-1979

Janda T, Szalai G, Tari I \& Pa'ldi E (1999) Hydroponic treatment with salicylic acid decreases the effects of chilling injury in maize (Zea mays L.) plants. Planta 208: 175-180.

Jiang MY, Yang WY \& Xu J (1994) Active oxygen damage effect of chlorophyll degradation in rice seedlings under osmotic stress. Acta Botanica Sinica 36: 289-295.

Jung C, Lyou SH, Yeu S, Kim MA, Rhee S, Kim M, Lee JS, Choi YD, Cheong JJ (2007) Microarray-based screening of jasmonate-responsive genes in Arabidopsis thaliana. Plant Cell Reports 26: 1053-1063.

Kalra YP (1998) Handbook of reference method for plant analysis. CRC Press, Washington, DC.

Kavir Kishor PB, Sangam S, Amrutha RN, Sri Laxmi P, Naidu KR, Rao KRSS, Sreenath Rao, Reddy KJ, Theriappan P \& Sreenivasulu N (2005) Regulation of proline biosynthesis, degradation, uptake and transport in higher plants: Its implications in plant growth and abiotic stress tolerance. Current Science 88(3): 424-438.

Khan W, Prithviraj B \& Smith DL (2003) Photosynthetic responses of corn and soybean to foliar application of salicylates. Journal of Plant Physiology 160: 485-492

Khattab HI Kh (2005). Responses of Eucalypt trees to insect feeding (gall-forming psyllid). International Journal of Agricultural Biology 7: 979-984. 
Kumar KB \& Khan PA (1982) Peroxidase and polyphenol oxidase in excised ragi (Eleusine coracana cv. PR 202) leaves during senescence. Indian Journal of Experimental Botany 20: 412-416.

Leitner M, Boland W \& Mithofer A (2005) Direct and indirect defences induced by piercing-sucking and chewing herbivores in Medicago truncatula. New Phytologist 167: 597-606.

Liang YC, Chen Q, Liu Q, Zhang W \& Ding R (2003) Exogenous silicon (Si) increases antioxidant enzyme activity and reduce lipid peroxidation in roots of salt-stressed barley (Hordium vulgare L.). J. Plant Physiol. 160:1157-1164.

Lu T \& Finkel T (2008) Free radicals and senescence. Exp Cell Res 314:1918-1922.

Maffei ME, Mithofer A, Arimura GI, Uchtenhagen H, Bossi S \& Bertea CM (2006) Effects of feeding Spodoptera littoralis on Lima beans leaves. III. Membrane depolarization and involvement of hydrogen peroxide. Plant Physiology 140:1022-1035.

Mahdavian K, Kalantari Kh. M \& Ghorbanli M (2007) The effect of different concentrations of salicylic acid on protective enzyme activities of peeper (Capsicum annuum L.) plants. Pakistan Journal of Biological Science 10(18): 3162-3165.

Marschner H (1986) Mineral nutrition of higher plants. Acad. Press. London.

Mittler R (2002) Oxidative stress, antioxidants and stress tolerance. Trends in Plant Science 7:405-410

Mur L, Kenton P \& Draper J (2005) In-plant measurements of oxidative bursts elicited by avirulent and virulent bacterial pathogens suggests that $\mathrm{H}_{2} \mathrm{O}_{2}$ is insufficient to elicit cell death in tobacco. Plant Cell \& Environment 28: 548-561

Nasir Kham M, Manzer HS, Mohammad F, Naeem M, Masroor M \& Kham A (2010) Calcium chloride and gibberellic acid protect linseed from $\mathrm{NaCl}$ stress by inducing antioxidative defence system and osmoprotectant accumulation. Acta Physiologica Plantarum 32: 121-132.

Neuenschwander U, Vernooij B, Friedrich L, Uknes S, Kessmann H \& Ryals J (1995) Is hydrogen peroxide a second messenger of salicylic acid in systemic acquired resistance? Plant Journal 8: 227-33.

Ni X, Quisenberry SS, Hegn-Moss J, Markwell J, Sarath G, Klucas R\& Baxendale F (2001) Oxidative responses of resistant and susceptible cereal leaves to symptomatic and nonsymptomatic cereal aphid (Hemiptera : Aphididae) feeding. Journal of Economic Entomology 94: 743-751.

Norman C, Howell KA, Millar AH, Whelan JM \& Day DA (2004) Salicylic acid is an uncoupler and inhibitor of mitochondrial electron transport. Plant Physiology 134: 492-501.

Omer AD, Granett J, Karban R \& Villa EM (2001) Chemically-induced resistance against multiple pests in cotton. International Journal of Pest Management 47: 49-54.

Orozco-Cardenas M \& Ryan CA (1999) Hydrogen peroxide is generated systematically in plant leaves by wounding and systemin via the octadecanoid pathway. Proceedings of the National Academy of Science USA 96: 6553-6557

Parra-Lobatoa MC, Fernandez-Garcia N, Olmosb E, Alvarez-Tinauta MC \& Gomez-Jiméneza MC (2009) Methyl jasmonate-induced antioxidant defence in root apoplast from sunflower seedlings. Environmental and Experimental Botany 66:9-17.

Pena-Cortes H, Albrecht T, Prat S,Weiler EW \& Willmitzer L (1993) Aspirin prevents wound-induced gene expression in tomato leaves by blocking jasmonic acid biosynthesis. Planta 191:123-28

Raju KS, Sheshumadhav M \& Murthy TGK (2008). Molecular diversity in the genus Nicotiana as revealed by randomly amplified polymorphic DNA. Physiology and Molecular Biology of Plants 14(4): 377-382.

Ruffer M, Steipe B \& Zenk MH (1995) Evidence against specific binding of salicylic acid to plant catalase. FEBS Letters 377:175-80

Ryan CA (1992) The search for the proteinase inhibitor-inducing factor, PIIF. Plant Molecular Biology 19: 12333

Sadasivam S. \& Manickam A(1996). Biochemical Methods, Second Edition, New Age International. India.

Sarosh BR \& Meijer J (2007) Transcriptional profiling by cDNA-AFLP revels novel insights during methyl jasmonate, wounding and insect attack in Brassica napus. Plant Molecular Biology 64: 420-425.

Schoonhoven LM, Jermy T \& Loon van JJA (1998) Plants as insect food: not the ideal. pp. 83-120 in: InsectPlant Biology. Chapman and Hall, London, United Kingdom.

Serrano R \& Gaxiola R (1994) Microbial models and salt stress tolerance in plants. Critical Reviews in Plant Science 13: 121-138.

Shirasu K, Nakajima H, Rajasekhar K, Dixon RA \& Lamb C (1997) Salicylic acid potentiates an agonistdependent gain control that amplifies pathogen signals in the activation of defence mechanisms. Plant Cell 9: 261-270

Singleton VL \& Rossi JA (1965) Colorimetry of total phenolics with phosphomolybdicphosphotungstic acid reagents. American Journal of Enology \& Viticulture 16: 144-158.

Smirnoff N, Conkin PL \& Loewus FA (2001) Biosynthesis of ascorbic acid in plants: a renaissance. Annual Review of Plant Physiology \& Plant Molecular Biology 52:437-467. 
Stevens J, Senaratna T \& Sivasithamparam K (2006) Salicylic acid induces salinity tolerance in tomato (Lycopersicon esculentum cv. Roma): associated changes in gas exchange, water relations and membrane stabilisation. Plant Growth Regulation 49:77-83.

Thaler JS, Fidantsef AL, Duffey SS \& Bostock RM (1999) Trade-offs in plant defence against pathogens and herbivores: a field demonstration of chemical elicitors of induced resistance. Journal of Chemical Ecology 25: 1597-1609.

Thaler JS, Stout MJ, Karban R \& Duffey SS (1996) Exogenous jasmonates stimulate insect wounding in tomato plants (Lycopersicon esculentum) in the laboratory and field. Journal of Chemical Ecology 22: 1767-1781.

Trevisan MTS, Scheffer JJC \& Verpoorte R (2003) Peroxidase activity in hop plants after infestation by red spider mites. Crop Protection 22: 423-424.

Van Breusegem F, Vranova E, Dat JF \& Inze D (2001) The role of active oxygen species in plant signal transduction. Plant Science 161: 405-414

Velikova V, Yordanov I \& Edreva A (2000) Oxidative stress and some antioxidant systems in acid rain-treated bean plants: protective roles of exogenous polyamines. Plant Science 151: 59-66.

Wu JC, Qiu ZH, Li Ying J, Dong B\& Gu HN (2004) Changes of zeatin riboside content in rice plants due to infestation by Nilaparvata lugens (Homoptera: Delphacidae). Journal of Economic Entomology 97: 19171922.

Yildirim E, Turan M \& Guvenc I (2008) Effect of foliar salicylic acid applications on growth, chlorophyll, and mineral content of cucumber grown under salt stress. Journal of Plant Nutrition 31: 593-612.

Zeneli G, Krokene P, Christiansen E, Krekling T \& Gershenzon J (2006) Methyl jasmonate treatment of mature Norway spruce (Picea abies) trees increases the accumulation of terpenoid resin components and protects against infection by Ceratocystis polonica, a bark beetle-associated fungus. Tree Physiology 26: 977-988.

Zhu Z, Wei G, Li J, Qian Q \& Yu J (2004) Silicon alleviates salt stress and increases antioxidant enzymes activity in leaves of salt-stressed cucumber (Cucumis sativus L.). Plant Science 167: 527-533

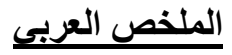

التخلب علي العربي إجهاد الأكسدة الناتجة عن إصابة نباتات الفاصوليا بالعنكبوت الأحمر وذللك من خلال إستخدام المحفز ات سعد فاروق *و محمد عثمان

$$
\text { قسمى النبات* و الحيوان ** الزر اعى ـ كلية الزر اعة- جامعة المنصورة- مصر }
$$

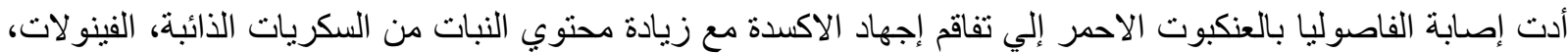

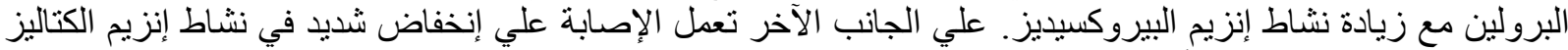

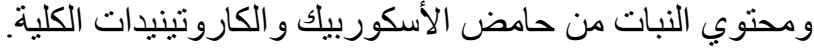

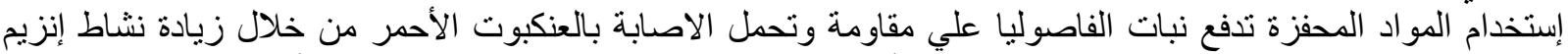

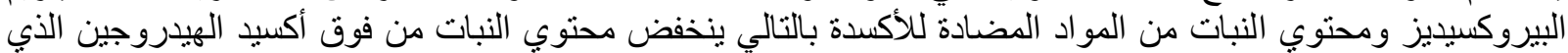

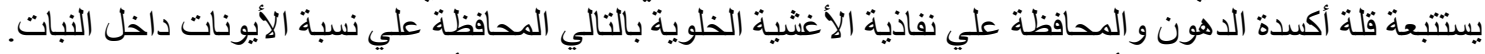

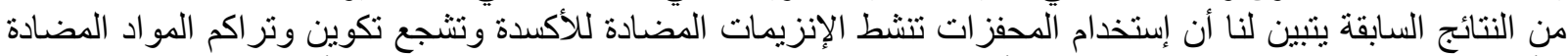

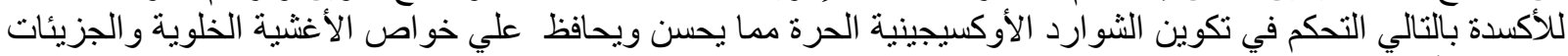

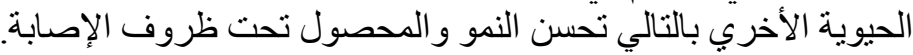

